\title{
WSKAŹNIKI ZRÓWNOWAŻONEGO ROZWOJU ENERGETYKI
}

\section{Streszczenie}

Celem artykułu jest przedstawienie pojęcia zrównoważonego rozwoju energetyki i wskaźników służących ocenie rozwoju energetyki w wymiarach: społecznym, ekonomicznym i ekologicznym. Została podjęta próba oceny pod kątem przydatności wskaźników do monitorowania zrównoważonego rozwoju energetyki w Polsce.

Zrównoważony rozwój energetyki to proces trwałego, bezpiecznego i efektywnego zapewniania energii na potrzeby zrównoważonego rozwoju. Wzorcem, który sprzyja do stworzenia zespołu wskaźników monitorujących ten rozwój, jest system zaproponowany przez IAEA. Stosowane na poziomie unijnym wskaźniki Eurostatu nie dostarczaja natomiast wystarczającej informacji szczególnie o badaniach i porównaniach wymiaru społecznego.

Monitoring zrównoważonego rozwoju energetyki powinien być bardzo funkcjonalny w ocenie realizacji Strategii na rzecz Odpowiedzialnego Rozwoju. Zestaw wskaźników proponowanych w tej strategii do oceny jej postępów jest bardzo jednostronny i ograniczony. Zastosowanie zestawu wskaźników, kompleksowo ujmujących rozwój energetyki, może przyczynić się do określenia tego rozwoju w sposób bardziej zrównoważony.

Wskaźniki stosowane przez Eurostat nie pozwalają na monitorowanie zrównoważonego rozwoju energetyki, a jedynie wybranych jego elementów. Jednocześnie Główny Urząd Statystyczny nie przygotowuje odrębnych opracowań na temat zrównoważonego rozwoju krajowej energetyki. Dla oceny zrównoważonego rozwoju energetyki na poziomie krajowym i porównań międzynarodowych, wskaźniki moga jednak być uzupełnione na podstawie danych z istniejących opracowań.

Słowa kluczowe: zrównoważony rozwój, wskaźniki rozwoju energetyki

\section{INDICATORS OF SUSTAINABLE ENERGY DEVELOPMENT}

\section{Summary}

The aim of the paper is to present the concept of sustainable energy development and indicators for evaluating the development of the energy sector in social, economic, and ecological dimensions. An attempt is also made to evaluate the usefulness of the indicators for monitoring the development of sustainable energy in Poland.

Sustainable energy development means a process of sustainable, safe and effective energy supply for sustainable development. The system that the IAEA proposes to develop relies on a set of monitoring indicators, and seems to be a useful model, although the EU-level Eurostat indicators do not provide sufficient information, particularly for the study and comparison of the social dimension. 
Monitoring of sustainable energy development should be very helpful in evaluating the implementation of the Strategy for Responsible Development. The set of indicators proposed in this strategy for assessing its progress is very one-sided and limited. The use of a set of indicators that comprehensively address the development of energy could contribute.

The indicators used by Eurostat do not allow monitoring of the sustainable development of the energy sector but only its selected components. GUS (the Central Statistical Office in Poland) also does not prepare separate studies on the sustainable development of the national energy sector. For the assessment of sustainable energy development at national level and for international comparisons, indicators may, however, be supplemented on the basis of data from the existing studies.

Key words: sustainable development, energy indicators

JEL classification: Q01, Q48, C82

\section{Wstęp}

Energia jest istotnym czynnikiem działań na rzecz zrównoważonego rozwoju. Wiele krajów, dążących do tego celu, tworzy nową koncepcję rozwoju energetyki i dokonuje oceny swoich systemów energetycznych pod kątem zgodności z celami zrównoważonego rozwoju. Powstały także międzynarodowe inicjatywy partnerstwa na rzecz wskaźników zrównoważonego rozwoju energii. Ich zadaniem jest dostarczenie analitycznego narzędzia do oceny obecnych wzorców produkcji i wykorzystania energii na poziomie krajowym. Przygotowywane są ogólne wytyczne i metodologie opracowywania krajowych wskaźników związane z monitorowaniem wpływu polityki energetycznej na wymiary: społeczne, gospodarcze i środowiskowe zrównoważonego rozwoju [Vera, 2006]. Przykładem takiego zestawu wskaźników jest propozycja Międzynarodowej Agencji Energii Atomowej (IAEA). W Polsce ważnym wydarzeniem było powołanie Społecznej Rady do spraw Zrównoważonego Rozwoju Energetyki. Głównym zadaniem Rady było opracowywanie propozycji i koncepcji rozwiązań systemowych w obszarze polskiej energetyki w kontekście uwarunkowań unijnych i międzynarodowych. Jednak prace te nie zostały sfinalizowane.

W statystyce unijnej i krajowej wysiłki koncepcyjne skupiały się na stworzeniu dobrych wskaźników dotyczących energii w zrównoważonym rozwoju, choć nie stanowi on zestawu wskaźników, którego przeznaczeniem jest monitorowanie zrównoważonego rozwoju energetyki. W szczególności problem ten wiąże się ze statystyką publiczna, która powinna dostarczać informacji o monitorowaniu i ocenie postępów rozwoju zrównoważonego.

Celem artykułu jest sformułowanie pojęcia zrównoważonego rozwoju energetyki, jego wymiarów i przesłanek, a na tym tle wskaźników służących ocenie rozwoju energetyki w wymiarach: społecznym, ekonomicznym i ekologicznym. Jednocześnie podjęto próbę ich oceny pod względem przydatności do monitorowania zrównoważonego rozwoju energetyki w Polsce. 


\section{Pojęcie zrównoważonego rozwoju energetyki}

Pozyskiwanie i wykorzystanie energii jest istotnym składnikiem zrównoważonego rozwoju. W ramach nowej Agendy na rzecz Zrównoważonego Rozwoju 2030 przyjęto siedemnaście celów. Wśród nich jest także cel siódmy - zapewnienie wszystkim dostępu do stabilnej, zrównoważonej i nowoczesnej energii po przystępnej cenie. W odniesieniu do tego celu zapisano: Pokonywanie wyzwan $i$ korzystanie z. licznych możliwości w dzisiejszym świecie wiqze sie z dostepem do energii. Jest ona konieczna w wykonywaniu pracy, zapewnieniu bezpieczeństwa, walce ze zmianami klimatycznymi, produkcji żwności cay wysitkach zwiekszajacych krajowe dochody. Zrównoważona energia to szansa na lepsza prayszłość, mo że ona bowiem przęsztatcic ṡycie człtowieka, całe gospodarki, a nawet naszq planete [Sustainable Development Goals..., 2015].

Polityka energetyczna Unii Europejskiej i akty prawne dotyczące sektora elektroenergetycznego mają na celu realizację filozofii zgodnej z zasadami zrównoważonego rozwoju, przede wszystkim poprzez: rozwój technologii wykorzystujących odnawialne zasoby energii oraz rozwój skojarzonego wytwarzania ciepła i energii elektrycznej [Skoczkowski, 2002]. Zielona Ksiegga z marca 2006 roku stanowiła próbę wskazania kierunków strategii Unii Europejskiej zorientowanej w stronę zrównoważonego rozwoju energetyki [Europejska strategia..., 2006].

Wielu autorów wskazuje, że głównym obszarem równoważenia rozwoju energetyki jest polityka energetyczna. K. Prandecki zrównoważoną energetykę zdefiniował jako zamianę energii pierwotnej na elektryczną i cieplną oraz jej dostarczenie do odbiorcy końcowego w sposób umożliwiający zaspokojenie potrzeb obecnych i przyszłych pokoleń, uwzględniających: gospodarcze, społeczne i środowiskowe aspekty rozwoju człowieka. Podkreślił, że na podstawie tego terminu kwestie związane ze zrównoważoną konsumpcją energii należy traktować jako element polityki energetycznej, a nie samej energetyki. Według niego, zrównoważona energetyka to wciąż pojęcie teoretyczne, które na obecnym etapie rozwoju cywilizacyjnego powinno być pojmowane jako dążenie do jak najmniej szkodliwych dla środowiska metod przetwarzania i dystrybucji energii uwzględniających społeczne i gospodarcze potrzeby obecnego i przyszłych pokoleń [Prandecki, 2014, s. 247].

Pojęcie zrównoważenia jest również obecne w systemie energetycznym. Zrównoważony system energetyczny: powinien być oparty na kombinacji odnawialnych technologï pozyskiwania energï, odnawialnego transportu paliw, odnawialnego ciepla, redukcïi popytu, efektywności wykorzystania, a takèze kogeneracji produkcji energii [Mitchel, 2010]. Cechami takiego systemu są:

- nacisk na długotrwałe cele ekonomiczne i środowiskowe;

- wzrost wykorzystania odnawialnych źródeł energii;

- $\quad$ rosnąca penetracja nowych technologii w zakresie wytwarzania i zarządzania;

- działanie na rynkach konkurencyjnych;

- rosnący nacisk na uwzględnienie kosztów zewnętrznych;

- działanie na rynkach międzynarodowych o jednakowych regułach konkurencji [Wach, 2008]. 
Szczególną rolę w procesach równoważenia rozwoju w odniesieniu do energetyki przypisuje się odnawialnym źródłom energii. Jeszcze w pierwszej dekadzie tego wieku często wskazywano, że trudno jest wyobrazić sobie sytuację, w której całość pozyskiwanej energii pochodziłaby jedynie ze źródeł odnawialnych. Za główne bariery uznawano: ograniczone zdolności człowieka do magazynowania energii elektrycznej, duże koszty, brak powszechnej zdolności do masowej produkcji instalacji, a przede wszystkim brak woli politycznej [Malko, 2006]. Współcześnie: zrównoważona energetyka jest

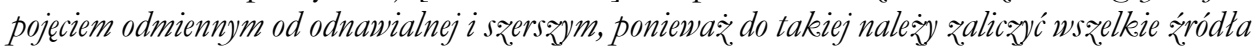
z. relatywnie dtugim cyklem sycia i niskim wplywem na środowisko [Prandecki, 2014, s. 243].

W tym kontekście trudno zgodzić się z konkluzją K. Prandeckiego, że wzrost efektywności energetycznej jest tylko pozornie skutecznym narzędziem służącym osiagnięciu zrównoważonej energetyki. Powołuje się on na paradoks Jevonsa, który jeszcze w XIX wieku stwierdzil, że wraz ze wzrostem efektywności urządzeń wykorzystujacych dany rodzaj energii pierwotnej, wzrasta ogólne zużycie energii. Jednak wynika to ze wzrostu liczby odbiorców posiadających wprawdzie więcej oszczędniejszych odbiorników energii, ale zużywających tańszą energię w większych ilościach.

Obecnie następuje wzrost efektywności energetycznej i spadek cen energii ze źródeł odnawialnych. Zatem w perspektywie wzrost efektywności energetycznej powinien sprzyjać rozwojowi wykorzystania odnawialnych źródeł energii, czyli procesowi, który jest eksponowany w niemal wszystkich wypowiedziach na temat zrównoważonego rozwoju energetyki. W polityce energetycznej i strategiach rozwoju należałoby więc preferować te jej rodzaje, które rzeczywiście cechuje potencjalnie nieograniczona podaż. Taki kierunek działań powinien być wiodący w działaniach na rzecz równoważenia rozwoju energetyki. Ze względu na szerokie wykorzystanie energetyki odnawialnej będzie przyczyniać się do większej spójności w wymiarach: terytorialnym, społecznym i gospodarczym.

Warto zauważyć, że w odniesieniu do rozważań na temat rozwoju zrównoważonego jako procesu należy dokonać rozróżnienia na dwa zagadnienia, a mianowicie zrównoważenia i rozwoju zrównoważonego. Pierwsze z pojęć wiąże się z sytuacją statyczna, gdzie jest badany stan, natomiast drugie z nich jest sytuacją dynamiczną, w której przedmiotem badań są zmiany [Zrównoważenie..., 2013, s. 14].

W świetle przedstawionych wyżej uwag można przyjąć, że zrównoważony rozwój energetyki to proces trwałego, bezpiecznego i efektywnego zagwarantowanie energii na potrzeby zrównoważonego rozwoju. Trwałość oznacza tu zagwarantowanie dostępu do energii z zachowaniem zasady sprawiedliwości międzypokoleniowej. Zrównoważenie rozwoju to równowaga między przynajmniej trzema jego wymiarami, tj.: społecznym, gospodarczym i ekologicznym.

\section{Wymiary zrównoważonego rozwoju energetyki}

Zrównoważony rozwój energetyki służy poprawie jakości życia w sposób trwały. Wydajny i niezawodny system energetyczny sprzyja tworzeniu spójności w wymiarze: społecznym, ekonomicznym i terytorialnym (ekologicznym), co jest typowe dla zrównoważonego rozwoju. Niekiedy wyodrębnia się także wymiar instytucjonalny. 
Wymiar społeczny zrównoważonego rozwoju energetyki wiąże się z wieloma aspektami. Dostępność energii ma bezpośredni wpływ na możliwości zatrudnienia i ubóstwo. W szczególności relatywnie droga energia nadmiernie obciąża budżety gospodarstw domowych i jest czynnikiem zniechęcającym do inwestowania i przedsiębiorczości. Sposób wytwarzania energii, a także korzystania z niej oddziałuje na zdrowie, zwłaszcza przez zanieczyszczenie środowiska. Dostępność i jakość energii pośrednio również kształtują: możliwości edukacji, bezpieczeństwo i poczucie bezpieczeństwa oraz włączenia lub wykluczenia społecznego. Aspekt społeczny to zarazem bezpieczeństwo pracy i ograniczenie ryzyka awarii, a czynniki te wpływają na wypadki spowodowane: wydobyciem, konwersja, przesyłem, dystrybucją i wykorzystaniem energii.

Nowoczesne gospodarki potrzebują niezawodnego i niekosztownego zaopatrzenia w energię. Istotną rolę odgrywa jej dostępność do nowoczesnych usług pozwalajacych na obniżanie kosztów. Rozwój energetyki i usług na szczeblu lokalnym jest czynnikiem zwiększania wydajności i wzrostu konkurencyjności, a jednocześnie oddziałuje na miejsca pracy i wydajność pracowników oraz na ich dochody.

Ważną rolę w rozwoju gospodarki i kształtowania jej struktury odgrywa efektywność energetyczna. Ma ona duże znaczenie dla rozwoju technologii. Kształtuje preferencje i zachowania konsumentów. Jest czynnikiem współokreślającym koszty i konkurencyjność na rynku międzynarodowym.

Rozwiązanie problemu bezpieczeństwa energetycznego jest jednym z głównych celów zrównoważonego rozwoju. Zasadnicze dla jego oceny są kwestie wymiany międzynarodowej netto energii oraz dostępności odpowiednich zapasów paliw.

Dywersyfikacja dostaw energii, rozwój energetyki rozproszonej, pewność dostaw sa nie tylko elementami zwiększania bezpieczeństwa ekonomicznego rozwoju energetyki, ale równocześnie maja znaczący wpływ na ceny energii i jej nośników na rynku krajowym. Kształtują konkurencję między dostawcami na tym rynku, co może przyczynić się nie tylko do obniżania cen, ale również ich różnicowania. Natomiast dotacje i podatki oraz niejawne subsydia moga zniekształcać wycenę nośników energii i samej energii. Ma to kluczowe znaczenie dla efektywnego zaopatrzenia w energię i jej wykorzystania oraz dla alokacji kapitału w inwestycje w poszczególne technologie energetyczne.

Produkcja, dystrybucja i wykorzystanie energii wywieraja presję na środowisko. Oddziaływanie na środowisko w dużym stopniu zależy od technologii i sposobu produkcji oraz wykorzystania energii.

Emisje zanieczyszczeń do atmosfery powoduja pogorszenie jakości powietrza. Szczególnie tzw. niska emisja niekorzystnie oddziałuje na ludzkie zdrowie. W warstwie przyziemnej zanieczyszczenie powietrza: ozonem, tlenkami siarki, tlenkami azotu, tlenkiem węgla, pyłem negatywnie także wpływa na: faunę i florę, na gleby i na wody. Znamiennym problemem sa transgraniczne i transregionalne przepływy zanieczyszczeń. Problemem globalnym są zarazem zmiany klimatyczne, które w znacznej mierze wywołują emisje gazów cieplarnianych z sektora energetycznego.

Jednocześnie rozwój energetyki wpływa na przekształcania przestrzeni i krajobrazu. Dotyczy to nie tylko procesów wydobycia i spalania węgla, ale również budowania zapór i zbiorników na ciekach wodnych, pozyskiwania drewna opałowego, przekazywania rolniczej przestrzeni produkcyjnej na uprawy energetyczne, budowy dużych 
instalacji fotowoltaicznych i farm wiatrowych, budowy i eksploatacji sieci przesyłowych i rurociagów. Procesy przekształcania energii, szczególnie z nośników nieodnawialnych, prowadzą do tworzenia odpadów, w tym odpadów promieniotwórczych, które wymagają odpowiedniej utylizacji.

Wymiar środowiskowy rozwoju energetyki ma istotne znaczenie dla pozostałych wymiarów zrównoważonego rozwoju. Wiąże się to przede wszystkim z dwiema kwestiami. Jedna z nich jest kształtowanie trwałości rozwoju, które zależy od efektywnego wykorzystywania zasobów nieodnawialnych i odpowiedniego zwiększania udziału zasobów odnawialnych. Druga to szeroko rozumiane bezpieczeństwo, które odnosi się nie tylko do niezawodności, lecz równocześnie do kosztów, w tym do kosztów zewnętrznych rozwoju energetyki.

\section{Przesłanki tworzenia wskaźników zrównoważonego rozwoju energetyki}

Wyodrębnienie energetyki jako obszaru współtworzącego zrównoważony rozwój jest podawane w najczęściej cytowanej w polskiej literaturze klasyfikacji wskaźników zrównoważonego rozwoju, zaproponowanej przez T. Borysa [Borys, 1990]. Zostały one zaliczone do grupy wskaźników sektorowych.

Podstawowa przesłanką tworzenia zestawu wskaźników jest operacjonalizacja koncepcji na potrzeby kontroli realizowanych celów zapisanych w dokumentach: strategicznych, politycznych, planistycznych, opracowywanych na różnych poziomach terytorialnych (od lokalnego po globalny). Jednocześnie odwrotnie - zasadniczym narzędziem monitoringu, które w sposób wymierny opisuje koncepcję tego rozwoju, sa właśnie wskaźniki. Najważniejszą cechą wskaźników jest porównywalność ich wartości. Nie mniej ważna jest poprawność formalna i przydatność merytoryczna wskaźnika, czyli jego związek relacyjny z opisywanym zagadnieniem [Stanny, Czarnecki, 2011, s. 26-27].

Wskaźniki powinny w sposób wymierny oddawać istotę tej koncepcji rozwoju. Konieczne jest występowanie związku merytorycznego z opisywanym zjawiskiem, np. dzięki odpowiedziom na pytania: czy rzeczywiście określony wskaźnik wyraża istotę zrównoważonego rozwoju i jaką konkretnie dziedzinę zrównoważonego rozwoju opisuje [Borys, Fiedor, 2008].

Potrzeba modernizacji statystyki europejskiej w odniesieniu do problemu zrównoważonego rozwoju energetyki była już wyrażana kilkakrotnie. Wprawdzie w Rozporzadzeniu Parlamentu Europejskiego i Rady (WE) nr 1099/2008 nie ma wprost odniesienia do zrównoważonego rozwoju energetyki, jednak w preambule znalazły się sformułowania, które pośrednio do tego problemu nawiazzuja: Wspólnota potrzebuje precysyjnych $i$ aktualnych danych dotyczacych ilosici energii, jej form, źródet, wytwarzania, dostaw, przemian $i$ zusycia, w celu monitorowania wplynu $i$ konsekwencij funkcjonowania jej polityki w driedzinie energii. Wskazano również, że tradycyjnie statystyka energii koncentrowała się na podaży energii oraz na energii pochodzącej ze źródeł kopalnych. Wynikaja z tego nowe zadania: w ciagu najblizssych lat statystyka ta musi w wiekssym stopniu wnzgledniać wieksza wiedze na temat zusizcia energii finalnej, energii ze źródet odnawialnych $i$ energii jadrowej oraz ich monitorowanie. (...) 
W najbliższej prayszz̨ości powinny zostać uw zglednione dane statystyczne dotyczace energii jadrowej, a istotne dane dotyczace energii ze źródet odnawialnych powinny być coraz bardziej wabogacane. Podobnie w driedrinie efektywności energetycznej niezanykle praydatne by tyby szcregótowe dane statystyczne dotyczace mieszkealnictwa i transportu.

Potrzebę zmian podkreślono także w Rozporzad dzeniu Komisji (UE) nr 431/2014. Stwierdzono w nim, że: statystyka dotyczaca energii jest bardzo dynamiczna driedzina statystyki z̧ wəgledu na intensywny rozwój polityk. unijnych, postęp technologiczny $i$ znaczenie danych dotyczacych energii jako podstany celow Unii. $W$ zwiazku z, tym niezbedne sa regularne aktualizacje majace na celu dostosowanie zakresu zbierania danych statystycznych do rosnacych lub zmieniajacych sie potrzeb.

\section{Wskaźniki zrównoważonego rozwoju dla energii Międzynarodowej Agencji Energii Atomowej}

Międzynarodowa Agencja Energii Atomowej (MAEA) jest samodzielną organizacja w ramach systemu Narodów Zjednoczonych. Działalność MAEA skupia się na trzech podstawowych obszarach, a mianowicie: weryfikacja jądrowa, bezpieczeństwo jądrowe oraz promocja nauki i pokojowych zastosowań technik jądrowych. Dyskusje na temat wskaźników dotyczących roli energii w zrównoważonym rozwoju koncentrują się na kwestiach udziału źródeł węglowych i odnawialnych w miksie energetycznym, stąd warto sięgnąć po propozycje formułowane przez organizację zajmującą się energetyka jądrowa. Jest to obszerny zestaw wskaźników. Zostały opracowane zgodnie z tymi samymi koncepcjami stosowanymi przez Komisję Narodów Zjednoczonych w sprawie Zrównoważonego Rozwoju (CSD).

Zestaw obejmuje 30 wskaźników, podzielonych na trzy wymiary (społeczny, gospodarczy i środowiskowy) [Energy indicators..., 2005]. Nie zawiera wskaźników instytucjonalnych. Tłumaczy się to tym, że są one trudne do zmierzenia pod względem ilościowym. Obejmuja wiele kwestii, które będą miały swój realny kształt w przyszłości. Ponadto, zmienne mierzone wskaźnikami instytucjonalnymi sa zazwyczaj formą odpowiedzi na strukturalne lub polityczne potrzeby zrównoważonego rozwoju. $\mathrm{Na}$ przykład wskaźniki instytucjonalne mogą pomóc zmierzyć skuteczność krajowej strategii bądź planu zrównoważonego rozwoju energetycznego. Mogłyby również pomóc w monitorowaniu postępów w tym kierunku. Mimo ich przydatności w tym obszarze, nie znalazły się w omawianym opracowaniu.

Wskaźniki podzielono na 7 tematów i 19 podtematów. Niektóre wskaźniki można sklasyfikować w więcej niż jednym wymiarze. Co więcej, każdy wskaźnik może reprezentować grupe powiązanych wskaźników, potrzebnych do oceny określonego problemu. W tabelach: 1.-3. przedstawiono wskaźniki IAEA w wymiarach: społecznym, ekonomicznym i ekologicznym. 
TABELA 1.

Wskaźniki IAEA zrównoważonego rozwoju dla energii w wymiarze społecznym

\begin{tabular}{|l|l|l|}
\hline \multicolumn{1}{|c|}{ Temat } & \multicolumn{1}{|c|}{ Subtemat } & \multicolumn{1}{c|}{ Wskaźnik } \\
\hline Równość & Dostępność & $\begin{array}{l}\text { Udział gospodarstw domowych (lub populacji) } \\
\text { pozbawionych elektryczności czy innej formy } \\
\text { energii dostarczonej z rynku bądź silnie uzależ- } \\
\text { nionych od nierynkowej dostawy energii }\end{array}$ \\
\cline { 2 - 3 } & Przystępność & $\begin{array}{l}\text { Udział wydatków na paliwa i energię elektryczną } \\
\text { w budżetach gospodarstw domowych }\end{array}$ \\
\cline { 2 - 3 } & Zróżnicowania & $\begin{array}{l}\text { Wykorzystanie energii w gospodarstwach domo- } \\
\text { wych w relacji do grup dochodowych i w nawią- } \\
\text { zaniu do miksu paliwowego }\end{array}$ \\
\hline Zdrowie & Bezpieczeństwo & $\begin{array}{l}\text { Wypadki przy pracy podczas wytwarzaniu energii } \\
\text { na różnych etapach łańcucha paliwowego }\end{array}$ \\
\hline
\end{tabular}

Źródło: opracowanie własne na podstawie: [Energy indicators..., 2005].

TABELA 2.

Wskaźniki IAEA zrównoważonego rozwoju dla energii w wymiarze ekonomicznym

\begin{tabular}{|c|c|c|}
\hline Temat & Subtemat & Wskaźnik \\
\hline \multirow[t]{14}{*}{$\begin{array}{l}\text { Wzorce produkcji } \\
\text { i użytkowania }\end{array}$} & $\begin{array}{l}\text { Wykorzystanie } \\
\text { ogółem }\end{array}$ & Zużycie energii per capita \\
\hline & $\begin{array}{l}\text { Ogólna efektyw- } \\
\text { ność energetyczna }\end{array}$ & Roczne zużycie energii na jednostkę PKB \\
\hline & Efektywność & Efektywność konwersji i dystrybucji energii \\
\hline & \multirow[t]{2}{*}{ Produkcja } & Relacja rezerw do produkcji energii \\
\hline & & Relacja zasobów do produkcji energii \\
\hline & \multirow{5}{*}{$\begin{array}{l}\text { Wykorzystanie } \\
\text { końcowe }\end{array}$} & Energochłonność przemysłu \\
\hline & & Energochłonność rolnictwa \\
\hline & & Energochłonność usług i handlu \\
\hline & & Energochłonność gospodarstw domowych \\
\hline & & Energochłonność transportu \\
\hline & \multirow[t]{3}{*}{$\begin{array}{l}\text { Dywersyfikacja } \\
\text { (miks paliwowy) }\end{array}$} & $\begin{array}{l}\text { Udziały paliw w produkcji i konsumpcji energii } \\
\text { oraz energii elektrycznej }\end{array}$ \\
\hline & & $\begin{array}{l}\text { Udziały paliw niewęglowych w produkcji i kon- } \\
\text { sumpcji energii oraz energii elektrycznej }\end{array}$ \\
\hline & & $\begin{array}{l}\text { Udziały energii ze źródeł odnawialnych w produk- } \\
\text { cji i konsumpcji energii oraz energii elektrycznej }\end{array}$ \\
\hline & Ceny & $\begin{array}{l}\text { Ceny energii końcowej, według paliwa i według } \\
\text { sektorów }\end{array}$ \\
\hline \multirow[t]{2}{*}{ Bezpieczeństwo } & Import & $\begin{array}{l}\text { Relacja import energii do całkowitego zaopa- } \\
\text { trzenia w energie pierwotną }\end{array}$ \\
\hline & $\begin{array}{l}\text { Nośniki strategicz- } \\
\text { ne }\end{array}$ & Krytyczne zapasy paliw do ich zużycia \\
\hline
\end{tabular}

Źródło: opracowanie własne na podstawie: [Energy indicators..., 2005]. 
TABELA 3.

Wskaźniki IAEA zrównoważonego rozwoju dla energii w wymiarze ekologicznym

\begin{tabular}{|c|c|c|}
\hline Temat & Subtemat & Wskaźnik \\
\hline \multirow[t]{3}{*}{ Atmosfera } & $\begin{array}{l}\text { Zmiany klima- } \\
\text { tyczne }\end{array}$ & $\begin{array}{l}\text { Emisja gazów cieplarnianych z produkcji energii } \\
\text { w stosunku do zużycia na jednego mieszkańca i na } \\
\text { jednostkę PKB }\end{array}$ \\
\hline & \multirow[t]{2}{*}{ Jakość powietrza } & $\begin{array}{l}\text { Stężenia zanieczyszczeń powietrza na obszarach } \\
\text { miejskich }\end{array}$ \\
\hline & & $\begin{array}{l}\text { Emisje zanieczyszczeń powietrza z systemów } \\
\text { energetycznych }\end{array}$ \\
\hline Woda & Jakość wody & $\begin{array}{l}\text { Zrzucane w ściekach ładunki zanieczyszczeń (w tym } \\
\text { oleju) z systemów energetycznych }\end{array}$ \\
\hline \multirow[t]{6}{*}{$\begin{array}{l}\text { Powierzchnia } \\
\text { ziemi }\end{array}$} & Jakość gleby & $\begin{array}{l}\text { Powierzchnia gleby, na której zakwaszenie przewyższa } \\
\text { ładunki krytyczne }\end{array}$ \\
\hline & Lasy & $\begin{array}{l}\text { Współczynnik wylesiania przypisany do zużycia ener- } \\
\text { gii (na skutek wykorzystania biomasy) }\end{array}$ \\
\hline & \multirow{4}{*}{$\begin{array}{l}\text { Wytwarzanie } \\
\text { i wykorzystanie } \\
\text { odpadów stałych }\end{array}$} & $\begin{array}{l}\text { Relacja masy substancji stałych na jednostkę ener- } \\
\text { gii wytworzonej }\end{array}$ \\
\hline & & $\begin{array}{l}\text { Stosunek ilości substancji stałych właściwie zutyli- } \\
\text { zowanych do ogólnej ilości odpadów stałych }\end{array}$ \\
\hline & & $\begin{array}{l}\text { Stosunek ilości stałych odpadów promieniotwór- } \\
\text { czych (skumulowanych dla wybranego okresu) do } \\
\text { produkcji energii }\end{array}$ \\
\hline & & $\begin{array}{l}\text { Stosunek ilości stałych odpadów promieniotwór- } \\
\text { czych, nadających się do sprzedaży, do całkowitej } \\
\text { ilości odpadów promieniotwórczych }\end{array}$ \\
\hline
\end{tabular}

Źródło: opracowanie własne na podstawie: [Energy indicators..., 2005].

Zbiór tych wskaźników stanowi propozycję całościowego (poza wymiarem instytucjonalnym) podejścia do problemu zrównoważonego rozwoju w odniesieniu do rozwoju energetyki. Ma także uniwersalny charakter - może być stosowany do różnych typów krajów i ich systemów energetycznych. Większość z nich nadaje się również do stosowania w układzie regionalnym.

\section{Wskaźniki Eurostatu dotyczące energii we wskaźnikach zrównoważonego rozwoju}

Dane dotyczące zrównoważonego rozwoju są dostarczane przez Europejski Urząd Statystyczny (Eurostat). W jego bazie znajduje się obszerna lista wskaźników zrównoważonego rozwoju (SDI), podzielona na dziesięć obszarów tematycznych [Sustainable Development Indicators, 2017]. Jednym z nich jest Zmiana klimatu i energia (Climate change and energy). Wskaźniki z tego obszaru przedstawiono w tabeli 4. 
TABELA 4.

Wskaźniki zrównoważonego rozwoju Eurostatu z obszaru zmiana klimatu i energia

\begin{tabular}{|c|c|}
\hline Wskaźnik/Indeks & Uwagi \\
\hline $\begin{array}{l}\text { Emisje gazów cieplar- } \\
\text { nianych }\end{array}$ & $\begin{array}{l}\text { Indeks przedstawia procentową zmianę rocznych, całkowitych emisji } \\
\text { w odniesieniu do emisji z } 1990 \text { roku, a także zmiany zwiazzane z emisjami } \\
\text { w roku bazowym. Lączna emisja gazów cieplarnianych jest wyrażona } \\
\text { w jednostkach ekwiwalentu } \mathrm{CO}_{2} \text {. Nie obejmuje: emisji i absorbcji zwiazza- } \\
\text { nych z użytkowaniem gruntów, zmianami użytkowania gruntów i leśnic- } \\
\text { twem, emisji z międzynarodowego transportu morskiego, z lotnictwa } \\
\text { międzynarodowego, z wykorzystania biomasy z odzyskiem energii. }\end{array}$ \\
\hline $\begin{array}{l}\text { Zużycie energii pierwot- } \\
\text { nej }\end{array}$ & $\begin{array}{l}Z \text { wyłączeniem wszystkich nieenergetycznych zastosowań nośników } \\
\text { energii. }\end{array}$ \\
\hline Oszczędność energii & $\begin{array}{l}\text { Wyraża procentowe zmniejszenie rzeczywistego zużycia energii pier- } \\
\text { wotnej. Służy porównaniu jej z celami strategii „Europa } 2020 \text { ”. Rokiem } \\
\text { bazowym jest } 2005 \text {. }\end{array}$ \\
\hline $\begin{array}{l}\text { Emisje gazów cieplar- } \\
\text { nianych według sekto- } \\
\text { rów }\end{array}$ & $\begin{array}{l}\text { Wyrażone w milionach ton ekwiwalentu } \mathrm{CO}_{2} \text {. Indeks obliczany dla } \\
\text { roku bazowego } 2000=100 \% \text {. }\end{array}$ \\
\hline Zależność energetyczna & $\begin{array}{l}\text { Wskazuje w procentach stopień, w jakim gospodarka opiera się na im- } \\
\text { porcie w celu zaspokojenia potrzeb energetycznych. Wskaźnik jest li- } \\
\text { czony jako przywóz netto podzielony przez sumę brutto zużycia ener- } \\
\text { gii w kraju i tankowania paliwa w krajowych portach (bunkier). }\end{array}$ \\
\hline $\begin{array}{l}\text { Udział energii odnawial- } \\
\text { nej w ostatecznym zuży- } \\
\text { ciu energii brutto }\end{array}$ & $\begin{array}{l}\text { Wskaźnik procentowy, obliczany na podstawie danych objętych Ro:po- } \\
\text { rzqadzeniem (WE) } n \text { r 1099/2008 w sprawie statystyke dotyczacych energii. }\end{array}$ \\
\hline $\begin{array}{l}\text { Zużycie energii brutto w } \\
\text { kraju na podstawie typu } \\
\text { paliwa }\end{array}$ & $\begin{array}{l}\text { Obliczany jako produkcja pierwotna + produkty odzyskane + całko- } \\
\text { wity import + odchylenia zasobów - całkowity eksport - bunkry. } \\
\text { Odpowiada to: dodatkowemu zużyciu, stratom w dystrybucji, stratom } \\
\text { transformacji i różnicom statystycznym. }\end{array}$ \\
\hline $\begin{array}{l}\text { Energia elektryczna wyt- } \\
\text { worzona ze źródeł odna- } \\
\text { wialnych }\end{array}$ & $\begin{array}{l}\text { Wskaźnik podawany w stosunku do zużycia energii brutto. Określa } \\
\text { udział energii elektrycznej wytwarzanej z odnawialnych źródeł energii } \\
\text { w krajowym zużyciu energii elektrycznej. Zużycie energii brutto w kraju } \\
\text { obejmuje całkowite krajowe wytwarzanie energii elektrycznej brutto } \\
\text { ze wszystkich paliw (w tym produkcja na własne potrzeby) oraz import } \\
\text { energii elektrycznej, a odlicza się jej eksport. }\end{array}$ \\
\hline $\begin{array}{l}\text { Udział energii odnawialnej } \\
\text { w zużyciu paliwa } \\
\text { w transporcie }\end{array}$ & $\begin{array}{l}\text { Oblicza się na podstawie danych objętych Rozporzadzeniem (WE) } \\
\text { nr 1099/2008 w sprawie statystyk dotyczacych energii. }\end{array}$ \\
\hline $\begin{array}{l}\text { Lączne wytwarzanie ciepła } \\
\text { i energii elektrycznej }\end{array}$ & $\begin{array}{l}\text { Podaje się w relacji procentowej do produkcji energii elektrycznej } \\
\text { brutto. }\end{array}$ \\
\hline $\begin{array}{l}\text { Zużycie energii w trans- } \\
\text { porcie w relacji do PKB }\end{array}$ & $\begin{array}{l}\text { Stosunek zużycia energii w transporcie (w tym: transport komercyjny, in- } \\
\text { dywidualny i publiczny, z wyłączeniem transportu morskiego i ruro- } \\
\text { ciagowego) do PKB (obliczonego metodą nawiązań łańcuchowych, } \\
\text { po kursie wymiany z } 2010 \text { roku). }\end{array}$ \\
\hline $\begin{array}{l}\text { Stawka podatkowa na } \\
\text { energię }\end{array}$ & $\begin{array}{l}\text { Wyrażona w euro za tonę ekwiwalentu ropy naftowej. Wskaźnik ten } \\
\text { określa się jako stosunek dochodów z tytułu podatku od energii do } \\
\text { końcowego zużycia energii, obliczony na rok kalendarzowy. }\end{array}$ \\
\hline
\end{tabular}

Źródło: opracowanie własne na podstawie: [Sustainable Development Indicators, 2017]. 


\section{Wskaźniki monitorowania osiagania celów w Strategii na rzecz Odpowiedzialnego Rozwoju}

Wizję rozwoju Polski określa Strategia na rzecz Odpowiedzialnego Rozwoju do roku 2020 (z perspektywą do 2030 roku) [Strategia na rzecz. Odpowiedzialnego Rozwoju..., 2017]. Jednym z istotnych elementów kształtujących rozwój i wpływających na spójność: gospodarczą, społeczną i terytorialną jest zapewnienie energii. Koncepcje rozwoju energetyki w strategii są głównie związane z dwoma obszarami horyzontalnymi, takimi jak energia oraz środowisko. W odniesieniu do tego obszaru zaproponowano wskaźniki służące monitorowaniu osiagania celów strategii. Podano je w tabeli 5.

TABELA 5.

Wskaźniki monitorowania osiągania celów Strategii na rzecz Odpowiedzialnego Rozwoju w obszarach związanych z rozwojem energetyki

\begin{tabular}{|c|c|}
\hline Wskaźnik/Indeks & Uwagi \\
\hline $\begin{array}{l}\text { Liczba obszarów zrównoważo- } \\
\text { nych energetycznie na poziomie } \\
\text { lokalnym }\end{array}$ & $\begin{array}{l}\text { Są to: klastry energii, spółdzielnie energetyczne itp. } \\
\text { (dane z Ministerstwa Energii) }\end{array}$ \\
\hline $\begin{array}{l}\text { SAIDI (System Average Inter- } \\
\text { ruption Duration Index) }\end{array}$ & $\begin{array}{l}\text { Podawany w minutach wskaźnik przeciętnego (śred- } \\
\text { niego) systemowego czasu trwania przerwy długiej } \\
\text { w dostawach energii elektrycznej. Jest współczynni- } \\
\text { kiem niezawodności, stanowiącym sumę iloczynów } \\
\text { czasu trwania przerwy w dostawie energii (w minutach) } \\
\text { i liczby odbiorców narażonych na skutki tej przerwy } \\
\text { w ciagu roku, podzielona przez łączną liczbę obsłu- } \\
\text { giwanych odbiorców przyłączonych do sieci (dane } \\
\text { z Ministerstwa Energii) }\end{array}$ \\
\hline $\begin{array}{l}\text { Stosunek pozyskania energii ogó- } \\
\text { łem do globalnego zużycia energii }\end{array}$ & W \% (dane z Ministerstwa Energii) \\
\hline Zużycie energii pierwotnej & W Mtoe (dane z Eurostatu) \\
\hline $\begin{array}{l}\text { Udział energii ze źródeł odna- } \\
\text { wialnych w końcowym zużyciu } \\
\text { energii brutto }\end{array}$ & $\mathrm{W} \%$ (dane z Eurostatu) \\
\hline $\begin{array}{l}\text { Liczba punktów wyposażonych } \\
\text { w moduły inteligentnego opomia- } \\
\text { rowania }\end{array}$ & W szt. (dane z Ministerstwa Energii) \\
\hline $\begin{array}{l}\text { Liczba punktów szybkiego łado- } \\
\text { wania pojazdów elektrycznych }\end{array}$ & W szt. (dane z Ministerstwa Energii) \\
\hline $\begin{array}{l}\text { Liczba punktów wolnego łado- } \\
\text { wania pojazdów elektrycznych }\end{array}$ & W szt. (dane z Ministerstwa Energii) \\
\hline $\begin{array}{l}\text { Krajowy wskaźnik średniego na- } \\
\text { rażenia na pył PM2,5 }\end{array}$ & $\mathrm{W} \mu \mathrm{g} / \mathrm{m}^{3}$ (dane z GIOŚ) \\
\hline Wskaźnik jakości powietrza & $\begin{array}{l}\text { W \% liczby stref z przekroczeniami poziomu dopusz- } \\
\text { czalnego pyłu PM10 (dane z GIOŚ) }\end{array}$ \\
\hline
\end{tabular}

Źródło: opracowanie własne na podstawie: [Strategia na rzecz Odpowiedzialnego Roz̨woju..., 2017, s. 325]. 
W przypadku wskaźników podanych w tabeli 5. uwagę zwraca fakt, że jako źródła danych nie podaje się GUS. Doświadczenie GUS i zasoby informacyjne w obszarze monitorowania zrównoważonego rozwoju oraz rozwoju energetyki są warte uwzględnienia. Mają one duże znaczenie przy ocenie spójności w rozwoju. Szczególnie problem spójności społecznej, najsilniej eksponowany w strategii, jest nieobecny wśród wskaźników proponowanych do monitorowania działań interwencyjnych w obszarach horyzontalnych zapowiadanych w strategii.

\section{Wskaźniki monitorowania problemów zrównoważonego rozwoju energetyki GUS}

Statystyka GUS obfituje we wskaźniki, które są poświęcone rozwojowi energetyki. Są one jednak rozproszone w różnych opracowaniach i bazach danych i nie tworza jednolitego obrazu zrównoważenia energetyki lub jej zrównoważonego rozwoju.

W opracowaniu poświęconym wskaźnikom zrównoważonego rozwoju [W skaźniki zrónnowa ̇onego rožwoju..., 2015] kategorią nadrzędna jest ład zintegrowany. Jest on układem docelowym rozwoju zrównoważonego. Oznacza spójne (niesprzeczne), jednoczesne tworzenie ładów: społecznego, gospodarczego, środowiskowego oraz instytucjonalno-politycznego na podstawie co najmniej umiarkowanego, antropocentrycznego systemu wartości. Strukturalną podstawę kształtowania ładu zintegrowanego tworzy system celów strategicznych o charakterze: społecznym, gospodarczym, środowiskowym i instytucjonalno-politycznym. Osiaganie tych celów jako pozytywnych stanów docelowych w określonej perspektywie czasowej rejestrują wskaźniki zrównoważonego rozwoju. Dokonując wyboru wskaźników zrównoważonego rozwoju, należy w miarę możliwości integrować łady dzięki wskaźnikom odnoszącym się do więcej niż jednego ładu [W skaźniki zrómnoważonego rozwoju..., 2015, s. 48].

W obrębie poszczególnych ładów znajdują się także wskaźniki, które dotyczą energetyki. W ramach ładu społecznego wyróżniono:

- narażenie ludności miejskiej na ponadnormatywne oddziaływanie pyłu PM10;

- narażenie ludności miejskiej na powietrze zanieczyszczone ozonem;

- $\quad$ zużycie energii elektrycznej w gospodarstwach domowych na 1 mieszkańca;

- $\quad$ strukturę przeciętnych miesięcznych wydatków na 1 osobę w gospodarstwach domowych według rodzajów (w tym użytkowanie mieszkania i nośniki energii).

W ładzie środowiskowym wskaźników związanych z energetyką jest więcej. Lad ten opisuja:

- emisja gazów cieplarnianych w ekwiwalencie $\mathrm{CO}_{2}$;

- emisja gazów cieplarnianych według sektorów;

- emisja gazów cieplarnianych na jednostkę zużytej energii;

- $\quad$ stan jakości powietrza (46 stref w skali kraju, w których dokonuje się oceny jakości powietrza);

- emisja zanieczyszczeń zakwaszających na $1 \mathrm{~km}^{2}$. 
Ład gospodarczy zawiera tylko jeden wskaźnik tego rodzaju, tj. energochłonność transportu w relacji do PKB.

Jednak w ramach ładu środowiskowego są wskaźniki dotyczące energii, które zwykle reprezentuja aspekt ekonomiczny, takie jak:

- $\quad$ udział energii ze źródeł odnawialnych w końcowym zużyciu energii brutto;

- $\quad$ udział energii ze źródeł odnawialnych w zużyciu paliw w transporcie;

- odsetek nakładów na środki trwałe w zakresie niekonwencjonalnych źródeł energii;

- energochłonność gospodarki,

Wiele mierników, głównie w wymiarze społecznym, zawiera publikacja pt.: Zuisycie energii w gospodarstwach domowych w 2015 roku [Zusycie energii w gospodarstwach domonych..., 2017]. Ważnym obszarem statystyki publicznej, z którego dane mogą być wykorzystane do monitorowania zrównoważonego rozwoju energetyki, jest efektywność energetyczna [Efektywność wykorsystania energii..., 2015]. Źródłem danych dla publikacji sa dane pochodzące z badań statystycznych statystyki publicznej z zakresu gospodarki paliwowo-energetycznej, prowadzonych przez GUS we współpracy z Ministerstwem Gospodarki, zgromadzone w bazie Odyssee. Do wskaźników nadających się do monitorowania problemów zrównoważonego rozwoju energetyki można zaliczyć:

- zużycie energii i energochłonność PKB;

- energochłonność produkcji;

- $\quad$ wskaźniki efektywności energetycznej w gospodarstwach domowych;

- wskaźniki efektywności energetycznej w sektorze usług;

- $\quad$ wskaźniki efektywności energetycznej w transporcie i elektroenergetyce;

- wskaźnik ODEX;

- $\quad$ wpływ czynników na zmianę zużycia energii finalnej.

Wskaźniki z tego obszaru szczególnie służą monitorowaniu ekonomicznego wymiaru zrównoważonego rozwoju energetyki. W ramach tego wymiaru cenne dane zawieraja opracowania GUS, takie jak: Energia ze źródet odnawialnych w 2015 roku [2016], Gospodarka paliwowo-energetyczna w latach 2014-2015 [2016], Zu̇̇ycie paliw i nośników energii w 2015 roku [2016].

W wymiarze ekologicznym monitorowania zrównoważonego rozwoju energetyki wiele informacji zawiera rocznik „Ochrona Środowiska” [Ochrona środowiska..., 2016c]. W wymiarze instytucjonalnym brakuje wskaźników GUS, które można by wprost zastosować. Możliwe wydaje się wykorzystanie wskaźnika proponowanego w ramach Strategii na rzecz Odpowiedzialnego Rozwoju [Strategia na ržecz. Odpowiedrialnego Rozwoju..., 2017] - Licz̧ba obszarów zrónnowa żonych energetycznie na poziomie lokalnym. Ponadto, stosunkowo łatwy do wprowadzenia wydaje się wskaźnik ukazujący odsetek gmin /miast posiadających program ograniczania niskiej emisji (PONE).

Wskaźniki stosowane przez GUS w odniesieniu do różnych aspektów rozwoju energetyki w części pokrywają się zakresem ze wskaźnikami Eurostatu. Podobnie jak one, jednak nie tworzą spójnego obrazu jej zrównoważonego rozwoju. Ich obfitość i różnorodność stwarza możliwość zbudowania systemu wskaźników do monitorowania zrównoważonego rozwoju energetyki. 
Wymaga to prac koncepcyjnych i ustalenia celów dla systemu monitorowania tego rozwoju. Podstawą może być nowa polityka energetyczna, która powinna ukazać się pod koniec 2017 roku. W mniejszym stopniu natomiast wskaźniki mogą służyć monitorowaniu postępów Strategii na rzecz Odpowiedzialnego Rozwoju. W niej rozwój energetyki został podporządkowany problemowi spójności społecznej. Jednak zastosowanie wskaźników opartych na koncepcji zrównoważonego rozwoju dawałoby szanse na większe zrównoważenie działań interwencyjnych oraz większe możliwości skorzystania ze środków unijnych w realizacji rozwoju energetyki.

Dokonując wyboru wskaźników, należy w miarę możliwości integrować łady dzięki wskaźnikom odnoszącym się do więcej niż jednego ładu [Wskaźniki zrównoważonego rozæwoju..., 2015, s. 48]. Warto sięgnąć do propozycji zestawu wskaźników IAEA, które mają bardziej kompleksowy charakter.

\section{Podsumowanie}

Zrównoważony rozwój energetyki jest istotnym składnikiem zrównoważonego rozwoju. To proces trwałego, bezpiecznego i efektywnego zapewniania energii na potrzeby zrównoważonego rozwoju. Może on być monitorowany zarówno w porównaniach międzynarodowych, jak i na poziomie unijnym, zwłaszcza przy ocenie osiagania celów polityki: energetycznej, klimatycznej i ekologicznej. Wzorcem, który służy stworzeniu zespołu wskaźników monitorujących ten rozwój, jest system zaproponowany przez IAEA. Stosowane na poziomie unijnym wskaźniki Eurostatu nie dostarczają wystarczającej informacji, szczególnie do badań i porównań wymiaru społecznego.

Monitoring zrównoważonego rozwoju energetyki powinien być bardzo praktyczny w ocenie realizacji Strategii na rzecz Odpowiedzialnego Rozwoju. Zestaw wskaźników proponowanych w tej strategii do oceny jej postępów jest bardzo jednostronny i ograniczony. Zastosowanie zestawu wskaźników, kompleksowo ujmujących rozwój energetyki, może przyczynić się do określenia tego rozwoju w sposób bardziej zrównoważony.

Wskaźniki wykorzystywane przez Eurostat nie pozwalają na monitorowanie zrównoważonego rozwoju energetyki, a jedynie wybranych jego elementów. Również GUS nie przygotowuje odrębnych opracowań na temat zrównoważonego rozwoju krajowej energetyki. Statystyka GUS poświęcona zrównoważonemu rozwojowi jest niewystarczająca do oceny zrównoważonego rozwoju energetyki. Przede wszystkim wiąże się to $z$ aspektem ekonomicznym.

Celem oceny zrównoważonego rozwoju energetyki na poziomie krajowym i porównań międzynarodowych, wskaźniki moga jednak być uzupełnione na podstawie danych z opracowań statystycznych dotyczących: efektywności energetycznej, gospodarki paliwowo-energetycznej, ochrony środowiska. W przypadku oceny na poziomie regionalnym, istotnej z punktu widzenia polityki spójności oraz w związu z zapowiadanymi w SOR działaniami interwencyjnymi w obszarze energii, wskazane byłoby przygotowanie odpowiednich przekrojów zbierania i prezentowania informacji statystycznej. 


\section{Literatura}

Borys T, Fiedor B., 2008, Operacjonalizacja i pomiar kategorii zrónnoważonego rozwoju praycsynek do dyskusji, [w:] Rachunki narodowe. Wybrane problemy i praylktady zastosowań, M. Plich (red.), GUS, Departament Rachunków Narodowych, Uniwersytet Lódzki, Wydział Ekonomiczno-Socjologiczny.

Borys T., 1999, Wskaźniki ekorožoju, Wydawnictwo „Ekonomia i Środowisko”, Białystok.

Efektywność wy koryystania energii w latach 2003-2013, 2015, GUS, Warszawa.

Energia ze źródet odnawialnych w 2015 roku, 2016a, GUS, Warszawa.

Energy indicators for sustainable development: guidelines and methodologies, 2005, International Atomic Energy Agency, Vienna.

Europejska strategia na rzecz, zrónnoważonej, konkurencyjnej $i$ beapiecznej energii, wersja ostateczna, 2006, Komisja Europejska, Bruksela, KOM (2006) 105.

Gospodarka paliwowo-energetyczna w latach 2014-2015, 2016b, GUS, Warszawa.

Malko J., 2007, Zrównoważony rozwój - cele i wyžwania elektroenergetyki, [w:] Teoria i praktyka zrónnoważonego rozwoju, A. Graczyk (red.), Wydawnictwo EkoPress, BiałystokWrocław.

Mitchel C., 2010, The Political Economy of Sustainable Energy, Palgrave Macmillan, Basingstoke.

Ochrona środowiska 2016, 2016c, GUS, Warszawa.

Prandecki K., 2014, Teoretycžne podstany zrównoważonej energetyki, [w:] Polityka gospodarcza w ok resie transformaciji i kryyysu, A. Barteczek, A. Rączaszek (red.), „Studia Ekonomiczne”, nr 166, Uniwersytet Ekonomiczny w Katowicach.

Rozporzadzenie Komisji (UE) nr 431/2014 z dnia 24 kwietnia 2014 roku zmieniajace rozporzadzenie Parlamentu Europejskiego i Rady (WE) nr 1099/2008 w sprawie statystyki energii w odniesieniu do wdrażania rocznych statystyk dotyczacych zuїycia energii w gospodarstwach domowych (Tekst majacy znaczenie dla EOG), Dz. Urz. UE, L 131/1.

Rozporzadzenie Parlamentu Europejskiego i Rady (WE) nr 1099/2008 ₹ dnia 22 października 2008 roku w sprawie statystyki energii (Tekst majacy znaczenie dla EOG), Dz. Urz. UE, L 304/1.

Skoczkowski T., 2002, Strategiczne aspekty racjonalnej gospodarki energiq $i$ środowiskiem polityka efektywności energetycznej w Unii Europejskiej i Polsce, „Gospodarka Paliwami i Energia", nr 5-6.

Stanny M., Czarnecki A., 2011, Zrównoważony rozwój obszarów wiejskich Zielonych Ptuc Polski. Próba analisy empirycżnej, Instytut Rozwoju Wsi i Rolnictwa Polskiej Akademii Nauk, Warszawa.

Strategia na rzecz Odpowied rialnego Rozwoju do roku 2020 (zperspektywa do 2030 r.), 2017, Ministerstwo Rozwoju Departament Strategii Rozwoju, Warszawa, https://www.mr.gov.pl/ media/36848/SOR_2017_maly_internet_03_2017_aa.pdf (data wejścia: 17.05.2017).

Sustainable Development Goals. Cele Zrónnoważonego Rožvoju, 2015, Platforma SDG, UNIC, Warszawa, http://www.un.org.pl/cel7 (data wejścia: 17.05.2017).

Sustainable Development Indicators, 2017, Eurostat, http://ec.europa.eu/eurostat/web/ sdi/indicators (data wejścia: 17.05.2017). 
Vera I., 2006, Energy indicators for sustainable development, „Energy”, vol. 32, Issue 6.

Wach E., 2008, Polityka zrównoważonego rozwoju energetyčnego w gminach, Bałtycka Agencja Poszanowania Energii S.A., www.sape.org.pl/.../04_Wach_Polityka_zrowno wazonegorozwoju (data wejścia: 17.05.2017).

Wską̧niki zrównoważonego rozwoju Polski, 2015, GUS, WUS w Katowicach, Katowice.

Zrównoważenie polskiego rolnictwa. Powszechny Spis Rolny 2010, 2013, J.S. Zegar (red.), Główny Urząd Statystyczny, Warszawa.

Zusiycie energii w gospodarstwach domonych w 2015 roku, 2017, GUS, Warszawa.

Zusyccie paliw i nośnikón energii w 2015 roku, 2016d, GUS, Warszawa. 